\title{
Factors in the Sharing of Tacit Knowledge among Volunteer Firefighters
}

\author{
Oliveira Márcio ${ }^{1} \&$ Pinheiro Paulo ${ }^{2}$ \\ ${ }^{1}$ Instituto Politécnico de Leiria, Escola Superior de Educação e Ciências Sociais, Leiria, Portugal \\ ${ }^{2}$ Universidade da Beira Interior, NECE - Research Unit in Business Sciences, Covilhã, Portugal \\ Correspondence: Márcio José Sol Pereira Oliveira, Instituto Politécnico de Leiria, Escola Superior de Educação \\ e Ciencias Sociais, Campus 1 Rua Dr. João Soares Apt 4045, 2411-901 Leiria, Portugal. E-mail: \\ marcio.oliveira@ipleiria.pt
}

Received: April 2, 2019

doi:10.5539/ijbm.v14n9p54
Accepted: May 6, 2019

Online Published: August 5, 2019

URL: https://doi.org/10.5539/ijbm.v14n9p54

\begin{abstract}
The studies in the area of knowledge management, directed to non-profit organizations are scarce, as opposed to what happens in the private and public sector. The growing importance of the third sector and its institutions, in establishing a more just and balanced society, combating asymmetries and placing itself on the side of the neediest, justifies the attention of the academic community, in order to establish and adopt best practices to carry out their missions.

The choice of a case study of organizations such as the Portuguese fire brigades, unique in their action and identity, accompanies the need increasingly recognized by Portuguese society to enable these organizations to perform best in the face of tragic events in recent years in Portugal, particularly in the case of large fires.

This study focuses on analysing the sharing of tacit knowledge in non-profit organisations (NPOs) through the case of Portuguese volunteer firefighters (Vfs). A literature review on tacit knowledge sharing allowed the identification of indicators to share this knowledge. A quantitative methodology was followed, with data collection through questionnaires and the treatment of which was able to determine the indicators that influence each factor. We correspondingly applied exploratory factorial analysis to study the indicators for the tacit sharing of knowledge.
\end{abstract}

This returned three factors as leading to the sharing of tacit knowledge within the scope of these organisations: organisational culture, individual characteristics and organisational structure.

Keywords: Tacit knowledge sharing, indicators, factors, volunteer firefighters, non-profit organisations

\section{Introduction}

Portuguese VFs are non-profit organisations and provide the key line of intervention whether in terms of prevention or combatting fires and administering emergency assistance to persons and objects in case of accidents. They are made up of volunteer based structures in which recourse to professionals takes place exclusively for the provision of minimum services. Given the nature and the risks of the functions undertaken by these volunteers, studying the firefighter sharing of tacit knowledge would seem of particular importance given that such knowledge may prove decisive, especially in operationally dangerous scenarios. Furthermore, this importance also arises from the lack of any prior study on the sharing of tacit knowledge in these organisations.

This article seeks to grasp the tacit knowledge sharing processes among Portuguese VFs, identifying the main indicators and ascertaining the main factors determining this sharing.

The article starts out with a brief summary setting out the core information to these objectives, the methodological approach, the key conclusions, the limitations to this research as well as its originality and value. This follows the brief introduction and the keywords. We subsequently present the theoretical framework with an emphasis on the indicators proposed for the sharing of tacit knowledge and the most relevant factors. The following section then presents and discusses the results before we close with the conclusions and recommendations for future studies. 


\section{Theoretical Framework}

Tacit knowledge refers to a type of knowledge that is neither easy to describe nor communicate (Polanyi, 1962 and 1966). According to Polanyi (1996), knowledge may be present in both explicit and tacit forms. In turn, Nonaka (1994) maintains that explicit knowledge is codified and may be easily communicated and transferred as it is susceptible to presentation in the form of manuals, plans, procedures, among other means. In contrast, tacit knowledge is implicit, difficult to conceptualise, subjective and composed of individual experiences. Davenport and Prusak (1998) refer to tacit knowledge as difficult to codify in documents or databases, undergoing development and internalisation over long periods of time and within a certain specific cultural environment and frequently not representing a conscious process. Sveiby (1997) considers tacit knowledge as personal knowledge, difficult to express, formalise or share and that exists in an intangible format. Hence, tacit knowledge may not be susceptible to representation outside of the human mind (Hislop, 2009 and Mládková, 2012) and frequently subject to loss due to its subjective and intuitive nature. This nature commonly ensures that such knowledge does not get shared and communicated (Othman and Abdullah, 2010), and often lost whenever highly experienced members of staff leave organisations. Furthermore, according to Nonaka and Takeuchi (1995), Teece (2000) and Ivona (2009), around two thirds of information received within the working context undergoes transformation into tacit knowledge through in person interactions such as informal conversations, direct interactions, story-telling, mentoring, networking or internships which Mongkolajala et al. (2012) identify as requiring communication among working colleagues so as to be able to capture this type of knowledge. Goffin and Koners (2011) affirm that the transference of tacit knowledge requires extensive personal contact, regular interactions and trust among the parties involved. According to these authors, tacit knowledge gets shared when its owner or holder participates in a network or a community. According to Schmidt and Hunter (1993), the sharing of tacit knowledge takes place through practice and requires specifically favourable contexts. Nonaka (1994) and De Long and Fahey (2000) agree that tacit knowledge reflects human actions and their interactions with the social environment. Frappaolo and Wilson (2002) and O'Dell (2002) report that 75\% or more of an organisation's knowledge may be categorised as tacit knowledge, which correspondingly reflects how organisations such as VFs, operating in turbulent and dynamic environments, should encourage and foster its sharing.

Thus, in order to ascertain the existence of tacit knowledge sharing within the framework of organisations, we compiled the following set of indicators in keeping with the findings in the literature and that we applied in the present study in keeping with table 1.

Table 1. Indicators for the sharing of tacit knowledge, the lead authors and key ideas

\begin{tabular}{|c|c|c|}
\hline Indicators & Authors & Key idea \\
\hline $\begin{array}{l}\text { 1. Individual time } \\
\text { management }\end{array}$ & $\begin{array}{l}\text { Haldin-Herrgard } \quad(2000), \\
\text { Fahey and Prusak (2001) }\end{array}$ & $\begin{array}{l}\text { The dissemination of knowledge consists of a set of tasks that, due to the time they } \\
\text { consume, may not be compatible with the ongoing speed of the business world. } \\
\text { The sharing of tacit knowledge needs more time to be effective in comparison with } \\
\text { the sharing of explicit knowledge. }\end{array}$ \\
\hline 2. Shared language & $\begin{array}{l}\text { Szulanski } \quad(1996), \\
\text { Haldin-Herrgard } \quad(2000), \\
\text { Davenport and Prusak (1998) } \\
\text { and Disterer (2003) }\end{array}$ & $\begin{array}{l}\text { Effective and efficient tacit knowledge transfer processes cannot be subject to } \\
\text { failures in communication between the emitter and the receptor, hence, the } \\
\text { terminology and the expressions applied, which very often assume their own } \\
\text { connotations depending on the organisational context of application, should be } \\
\text { broadly understood by both parties. }\end{array}$ \\
\hline $\begin{array}{l}\text { 3. Mutual } \\
\text { confidence }\end{array}$ & $\begin{array}{l}\text { Roberts (2000) and } \\
\text { Davenport and Prusak (1998) }\end{array}$ & $\begin{array}{l}\text { The risks and uncertainties present in the sharing of tacit knowledge fall to the } \\
\text { extent that trust among the individuals participating in the organisation rises. } \\
\text { Establishing networks of trust depends on the sharing of social and cultural values } \\
\text { and shared expectations. }\end{array}$ \\
\hline $\begin{array}{l}4 . \quad \text { Relational } \\
\text { network }\end{array}$ & $\begin{array}{l}\text { Szulanski (1996), O’Dell and } \\
\text { Grayson (1998) }\end{array}$ & $\begin{array}{l}\text { One of the difficulties to tacit knowledge sharing derives from the poor diagnosis } \\
\text { and identification of the tacit knowledge needs of each organisational member and } \\
\text { as regards the quantity and quality of knowledge for acquisition to meet such } \\
\text { needs. Both the receptor and the emitter of knowledge do not know just who might } \\
\text { either hold or be interested in the knowledge they lack or that they hold. }\end{array}$ \\
\hline 5. Hierarchy & $\begin{array}{l}\text { Disterer (2003), O'Dell and } \\
\text { Grayson (1998) }\end{array}$ & $\begin{array}{l}\text { The organisational, hierarchical and bureaucratic structures hinder communication, } \\
\text { the sharing of information and ultimately, the sharing of tacit knowledge. Each } \\
\text { member acts in accordance with attaining and leveraging their own personal results } \\
\text { and rewards, which results in disincentives to exchanging experiences. }\end{array}$ \\
\hline
\end{tabular}




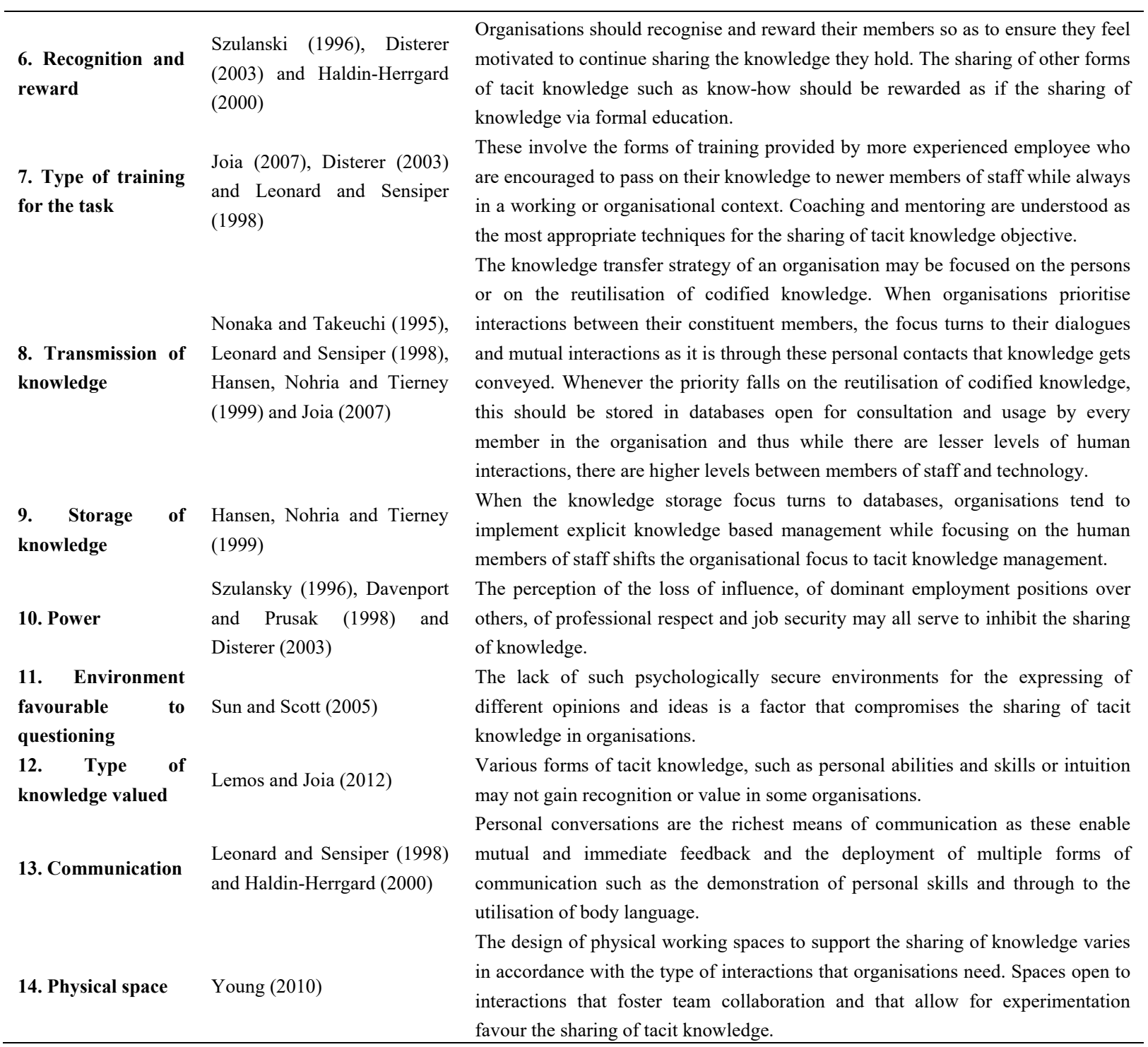

Source: By the authors.

Organisational culture, the characteristics of its individual members and the organisational structures are all of significant importance to the sharing of tacit knowledge.

Firstly, people in organisational contexts interact with each other and with the surrounding organisational culture and, according to Lemos and Joia (2012), this represents a determining factor to the sharing of tacit knowledge. Establishing a culture favourable to knowledge sharing increasingly reflects a critical factor for the success of organisations (Ndlela \& Toit, 2001; Davenport \& Prusak, 1998; Lee \& Kim, 2001). In turn, Jeng and Dunk (2013) state that we may define organisational culture as a unique system within which there is the ongoing sharing of certain values and behaviours. Within a knowledge sharing context, Davenport and Prusak (1998) identify how the organisational culture constitutes a determining factor for consideration given that this acts as the "infrastructure" where such sharing takes place. According to Long (1997), this organisational culture determines how knowledge, whether tacit or explicit, gets valued by the respective organisation alongside decisions over which knowledge to preserve and maintain as well as just what is able to generate advantages to the organisation. Jeng and Dunk (2013) defend how, especially when organisational change becomes necessary and giving the example of a shift in market paradigm, rewards should target the sharing of knowledge to the detriment of rewarding individual performance levels.

Furthermore, these same authors state that individual components, such as experience, reflection, internalisation and talent are equally determinant to such knowledge sharing practices. In keeping with how, as put forward by Eppler and Sukowski (2000), Gottschalk (2000) and Scott (2000), people are at the centre of organisational 
knowledge creation, individual characteristics also provide a critical factor to the sharing of tacit knowledge. Hence, Nonaka and Takeuchi (1995) consider that updating knowledge within the scope of an organisation may stem from the recruitment of new members of staff who bring in new knowledge or specific abilities that may subsequently be subject to sharing. Indeed, Lemos and Joia (2012) state that the more open people are to those in close proximity, the greater their predisposition to the sharing of tacit knowledge given that their actions favour the spending of more time with their colleagues, placing more trust and confidence in the relationships ongoing, attributing greater value to the insights and heuristic views of colleagues while also displaying higher interest in developing shared language with other professionals.

Organisation structures may also encourage or hinder the sharing of knowledge (Hopper, 1990; Caruana et al., 1998; and Ichijo et al., 1998) and hence constitutes a determining factor to the sharing of tacit knowledge. According to these authors, the organisational structure needs to incorporate sufficient flexibility so as to foster the sharing of knowledge among its members even when occupying different hierarchical levels. In addition, Menon and Varadarajan (1992), Nonaka and Takeuchi (1995) and O'Dell and Grayson (1999) identify how flexible organisational structures, less formal and decentralised, are more favourable to the sharing of tacit knowledge.

\section{Method}

The present research adopted an exploratory methodological approach so as to better understand the indicators for the sharing of tacit knowledge within the scope of VFs and just which factors most greatly influence such sharing. Based on the literature review, we identified fourteen indicators as set out in Table 1. According to these indicators, we then drafted a questionnaire that sought to ascertain the perceptions of the respondents as regards the prevalence of each of the indicators subject to analysis. The questionnaire contained two separate sections with the first made up of a set of generic questions about the respondent while the second featured fourteen multiple choice questions answered according to a five-point Likert scale varying from "totally disagree" to "totally agree". Each question sought to ascertain the level of agreement about the prevalence of that particular tacit knowledge sharing indicator.

We selected the VFs as the non-profit organisation studied in keeping with the voluntary bond under which the firefighters exercise their roles in areas of action as sensitive as the prevention and provision of assistance both in the case of fires and every type of accident. We would mention here that two major operational events took place in Portugal in 2017 with forest fires that year responsible for destroying over 500,000 hectares of land. The first event occurred between 17 and 24 June and saw the loss of 64 lives in addition to the destruction of 490 homes and 50 industrial units. The second, between 14 and 16 October, in the central region of Portugal, caused the death of 48 people and destroyed some 521 industrial units, responsible for some 4,500 jobs. These events refocused importance on the role of the VFs in terms of civil defence and triggered a set of reflections across civil society and that involve, according to the Report from the Independent Technical Commission set up in the wake of the aforementioned events, the need to endow operational firefighters with deeper knowledge, better qualifications and the need to adopt best practices for the governance and management of Portuguese forests. Hence, we chose volunteer firefighters as our respondents and guaranteed them anonymity for their voluntarily submitted answers. Correspondingly, the sample features a total of 380 firefighters. In order to identify and eliminate any eventual problems with the questionnaire, we carried out a pre-test with 32 firefighters from the Brasfemes fire station. The application of the questionnaire made recourse to an online Internet survey tool entitled Google Forms. Once the prevalence of the indicators was verified, an exploratory factorial analysis allowed to find the main fators in which the indicators grouped together. Thus, based on the analysis of the prevalence of each indicator, it was possible to find the factors that influence the sharing of tacit knowledge in voluntary fire brigades

\section{Presentation and Discussion of Results}

Having collected the data from the 380 respondents in the month of September 2018, we then verified the reliability and internal consistency of the indicators through recourse to Cronbach's alfa (0.877), which Hair et al (2005) maintain is the most commonly adopted and effective test of reliability and internal consistency. We then advanced with exploratory factorial analysis so as to obtain a reduction in the data through grouping them into factors and hence enabling the identification of the factors that effectively influence such knowledge exchanges and ascertain those indicators shaping each factor favourable to the sharing of tacit knowledge among VFs. We first applied Bartlett's sphericity test $(0.000)$ before obtaining the statistic from the Kaiser-Meyer-Olkin test (0.892), with both tests verifying the appropriateness of the data to factorial analysis. Subsequently, we applied the principal component analysis (PCA) method based on the correlation matrix so as to obtain the maximum 
number of factors responsible for the maximum variation in data.

Table 2. Principal component analysis

\begin{tabular}{ccccccc}
\hline \multicolumn{3}{c}{ Initial self-values } & \multicolumn{3}{c}{ Results of extracting the squared loads } \\
\hline Component & Total & variance $\%$ & cumulative $\%$ & Total & variance \% & cumulative \% \\
\hline $\mathbf{1}$ & 5.481 & 39.148 & 39.148 & 5.481 & 39.148 & 39.148 \\
$\mathbf{2}$ & 1.504 & 10.742 & 49.890 & 1.504 & 10.742 & 49.890 \\
$\mathbf{3}$ & 1.114 & 7.956 & 57.846 & 1.114 & 7.956 & 57.846 \\
$\mathbf{4}$ & .829 & 5.919 & 63.764 & & & \\
$\mathbf{5}$ & .780 & 5.570 & 69.335 & & \\
$\mathbf{6}$ & .703 & 5.022 & 74.357 & & \\
$\mathbf{7}$ & .606 & 4.325 & 78.682 & & \\
$\mathbf{8}$ & .587 & 4.192 & 82.874 & & \\
$\mathbf{9}$ & .468 & 3.345 & 86.219 & & \\
$\mathbf{1 0}$ & .464 & 3.312 & 89.531 & & & \\
$\mathbf{1 1}$ & .445 & 3.182 & 92.713 & & & \\
$\mathbf{1 2}$ & .372 & 2.660 & 95.372 & & & \\
$\mathbf{1 3}$ & .346 & 2.469 & 97.841 & & & \\
$\mathbf{1 4}$ & .302 & 2.159 & 100.000 & & & \\
\hline
\end{tabular}

Source: By the authors.

We established the minimum number of factors in accordance with the self-values while only maintaining self-values with a result of over 1 in keeping with the latent root method.

Finally, this study applied the Varimax orthogonal rotation method which, according to Hair et al. (2005), serves to simplify the factorial matrix columns in returning a clearer separation among the different factors.

Having carried out factorial analysis of the data obtained from the answers provided by the firefighters to the questionnaire, as duly described above, we are in a position to report the structure of the factors relevant to the transfer of tacit knowledge as duly set out in Table 3.

Table 3. Rotated component matrix

\begin{tabular}{lccc}
\hline \multicolumn{1}{c}{ Indicators } & Factors & \\
\hline & $\begin{array}{c}\text { 1 - Organisational } \\
\text { Culture }\end{array}$ & $\begin{array}{c}\text { 2 - Individual } \\
\text { Characteristics }\end{array}$ & $\begin{array}{c}\text { 3 - Organisational } \\
\text { Structure }\end{array}$ \\
\hline 11. Environment favourable to questioning & .736 & & \\
12. Type of knowledge valued & .721 & \\
13. Communication & .666 & & \\
14. Physical space & .591 & & \\
10. Power & .537 & .503 \\
8. Transmission of knowledge & .535 & .793 & \\
6. Recognition and reward & .451 & .760 & .754 \\
3. Mutual trust & & & .791 \\
2. Common language & & .469 & .637 \\
1. Individual management of time & & & .624 \\
5. Hierarchy & & & .557 \\
4. Relational network & & & \\
9. Storage of knowledge & & & \\
7. Type of training for the task & & & \\
\hline
\end{tabular}

Source: By the authors.

\subsection{Factor of Organisational Culture}

The first factor returned was "organisational culture" composed of the following indicators: 11 - Environment favourable to questioning, 12 - Type of knowledge valued, 13 - Communication, 14 - Physical space, 10 - 
Power, 8 - Transmission of knowledge, 6 - Recognition and reward and 7 - Type of training for the task.

This demonstrates how the prevailing organisational culture is essential to fostering an environment favourable to questioning and consequently, the sharing of tacit knowledge, where, in accordance with Cross et al. (2001), not only may each member openly recognise their ignorance as regards specific subjects but constructive criticism is also openly accepted. The role of organisational culture, as defined by Leonard and Sensiper (1998) and Haldin-Herrgard (2000), is to highlight just which type of knowledge gets valued and prioritising forms of tacit knowledge such as personal abilities or intuitions to the detriment of standardised and undifferentiated training programs in which logic and rationality serve as the dominant methods and most prevalent forms of communication. Furthermore, Leonard and Sensiper (1998) and Haldin-Herrgard (2000) state that nurturing personal and informal conversations constitutes a valid means of communication for the sharing of tacit knowledge as this facilitates the deployment of body language, the demonstration of personal abilities and skills and gaining optimal and immediate feedback. The encouragement or dissuasion of these types of interactions among staff and members is profoundly rooted in the organisational culture prevailing. This is closely bound up with the forms of communication and whether the physical spaces are appropriate to this same effect. Young (2010) maintains that spaces open to interactions, which foster collaboration among teams and enable experimentation, are favourable to the sharing of tacit knowledge. The availability of physical or even virtual spaces, such as the provision of access to social networks and teleconferencing facilities, interlinks with the organisational culture prevailing. This culture is also a core factor in perceptions over loss of power, influence or privileged labour position as regards other members of the organisation whenever sharing knowledge that the individual holds. According to Szulansky (1996), Davenport and Prusak (1998) and Disterer (2003), the privilege of holding rare knowledge and the association between this and an increase in power, more than just a matter of the organisational structure or individual perceptions, reflects something culturally embedded in the organisation. Even while tacit knowledge undergoes concentration at the personal level, it is the prevailing organisational culture that determines the focus of its transmission or sharing. The strategies adopted for this purpose, beyond individual preferences or impositions levied by organisational structures, emerge from the roots of the organisational culture given that, in accordance with Nonaka and Takeuchi (1995), Leonard and Sensiper (1998), Hansen, Nohria and Tierney (1999) and Joia (2007), whenever prioritising interactions among organisational members, the focus shall fall on dialogue and interaction to the detriment of codification and storing knowledge and information for subsequent consultation. Rewarding and recognising the sharing of tacit knowledge, beyond something merely decreed by the organisational structure, represents an integral component of the organisational culture prevailing. Szulanski (1996) and Disterer (2003) state that the individual motivations endowed on members of the organisation ensure this indicator ranks as an influential factor as regards individual characteristics. However, the recognition and mutual stimulation that may emerge among peers demonstrates how essential organisational culture is to determining the individual sensation of recognition and reward for the sharing of tacit knowledge. The type of specialist training that fosters the acquisition of competences and tacit knowledge for undertaking the tasks may be "stipulated" by the organisational structure even while its existence and predominance within the scope of the respective organisational culture emerges as highly favourable to the sharing of tacit knowledge. Disterer (2003) and Leonard and Sensiper (1998) describe how the adoption of processes such as mentoring and coaching reflects the importance that organisations attribute to the type of training susceptible to encouraging this sharing of tacit knowledge.

\subsection{Factor of Individual Characteristics}

The second factor returned incorporates the "individual characteristics" consisting of the following indicators: 3 - Mutual trust, 2 - Common language, 1 - Individual management of time, 4 - Relational network and 6 Recognition and reward.

Individual characteristics, innate to the persons making up any organisation, are determinant to the successful sharing of tacit knowledge. The capacity of any person to create and experience feelings of mutual trust among individuals favours the sharing of tacit knowledge. Roberts (2000) and Davenport and Prusak (1998) state that the sensation of reducing risks and uncertainties in the sharing of tacit knowledge are lower in keeping with the higher the individual capacity to foster stable, secure and trustworthy relationships among individuals. According to Haldin-Herrgard (2000), in the sharing of tacit knowledge, the greater the tacit experience, the greater the difficulty in its verbalisation and hence the sheer importance of utilising common language. Haldin-Herrgard (2000), Davenport and Prusak (1998) and Disterer (2003) place the emphasis on the emitter and the receptor being in harmony given that the experience of sharing knowledge is highly individualised and personalised and correspondingly dependent on participants adopting a language in which both apply the same terminology or expressions. Time is an increasingly scarce resource within the organisational framework and the sharing of tacit 
knowledge may represent a slow process extending over time (Davenport and Prusak, 1998). Indeed, the time available to each individual in organisational contexts requires channelling towards the sharing of tacit knowledge (Haldin-Herrgard, 2000), with members of staff thereby needing informing about the importance of this sharing. Furthermore, this sharing needs to take relational networks into account by attempting to gain the maximum leverage out of members who display the highest levels of tacit knowledge. in turn, O'Dell and Grayson (1998) state that both the emitter and the receptor of this knowledge may not know those who either have or need this knowledge, an aspect that the organisational structure might promote and fostering the approximation of the respective parties. However, the departure point for this process should stem from the individual drive to seek out tacit knowledge, or an impulse for its sharing, backed up by the internal relational network of the organisation.

Even while organisational culture fosters an environment favourable to rewarding and recognising the sharing of tacit knowledge, Szulanski (1996) and Disterer (2003) state that this only effectively corresponds to the intrinsic expectations of each individual. That which might actually serve as an incentive or a reward to a person might even generate counterproductive effects for others, hence requiring an exercise that facilitates the sharing of tacit knowledge but founded upon the intrinsic characteristics of individuals.

\subsection{Factor of Organisational Structure}

The third factor identified by these results is that of "organisational structure" that features the following indicators: 5 - Hierarchy, 4 - Relational network, 9 - Storage of knowledge, 7 - Type of training for the task and 8 - Transmission of knowledge.

As regards the organisational structure of the entities here subject to study, they deploy paramilitary type structures in which hierarchy remains significantly present in a pyramid shape and in which, according to Disterer (2003), bureaucracy and formality may serve as obstacles to the sharing of tacit knowledge. O'Dell and Grayson (1998) state that this style of structure favours behaviours that discourage exchanges of experience and tacit knowledge, given that their members, rather than seeking to obtain the objectives of the respective organisation, might instead strive to achieve their own objectives. Furthermore, Szulanski (1996), Fahey, and Prusak (2001) and Sun and Scott (2005) concur that the strong presence of a hierarchy leads to a reduction in the time, the flexibility and the willingness for informality, ideal to the sharing of tacit knowledge. In addition to the individual benefits that each member may draw from the relational network available, this indicator nevertheless also forms part of the organisational structure given that the relational network potentially gets harmed by undermining the hierarchy, in accordance with Davenport and Prusak (1998), and resulting in the members at the bottom of the hierarchical pyramid not having the same access to their fellow members at the top of the pyramid who have potentially greater stores of tacit knowledge and who might effectively contribute towards its effective sharing. Through means of the organisational structure, this relational network does not favour the sharing of tacit knowledge. More than simple individual will or the organisational culture, the organisational structure is responsible for orienting the focus of storing knowledge in databases that enable and foster the sharing of explicit knowledge or, in persons, nurturing the sharing of tacit knowledge. Nonaka and Takeuchi (1995); Leonard and Sensiper (1998), Hansen, Nohria and Tierney (1999) and Joia (2007) all state that, in such cases, a knowledge storage oriented strategy assumes a high level of knowledge personalisation in members of staff, thus, the organisational structure thereby privileges and promotes the sharing of tacit knowledge. This organisational structure takes on the implementation of strategies designed for tacit knowledge sharing and promoting specific types of training for this task, such as mentoring and coaching. According to Joia (2007), the adoption of strategies able to provide exchanges of experiences among members holding greater levels of tacit knowledge with their other, less experienced peers or whoever is new to the organisation is a facet within the reach of organisational structures with Lemos and Joia (2012) identifying how implementing this reflects the importance organisations actually attribute to the sharing of tacit knowledge. Even while the transmission of knowledge is intimately interconnected with organisational culture, the organisational structure holds responsibility for ensuring the terms and conditions for its effective transfer. Nonaka and Takeuchi (1995), Leonard and Sensiper (1998), Hansen, Nohria and Tierney (1999) and Joia (2007) find that when the organisational structure option focuses on adopting strategies designed to foster contacts between persons, this enables the sharing of tacit knowledge. Furthermore, Hansen, Nohria and Tierney (1999) report that when organisational structures foster strategies based on the reutilisation of codified knowledge, there lacks the scope for major interactions between persons but rather between persons and technologies and hence the focus turns towards the sharing of explicit knowledge. 


\title{
5. Conclusions and Recommendations
}

Taking into consideration the study objectives, we may conclude that the 14 indicators for the sharing of tacit knowledge put forward hold relevance to at least one factor for such sharing and with the indicators 4 Relational network, 6 - Recognition and reward, 7 - Type of training for the task and 8 - Transmission of knowledge all holding relevance in two of the three factors encountered. Through factorial analysis, we are able to conclude that the 14 indicators are eligible for grouping into three factors holding influence over the sharing of tacit knowledge as depicted in figure 1 .

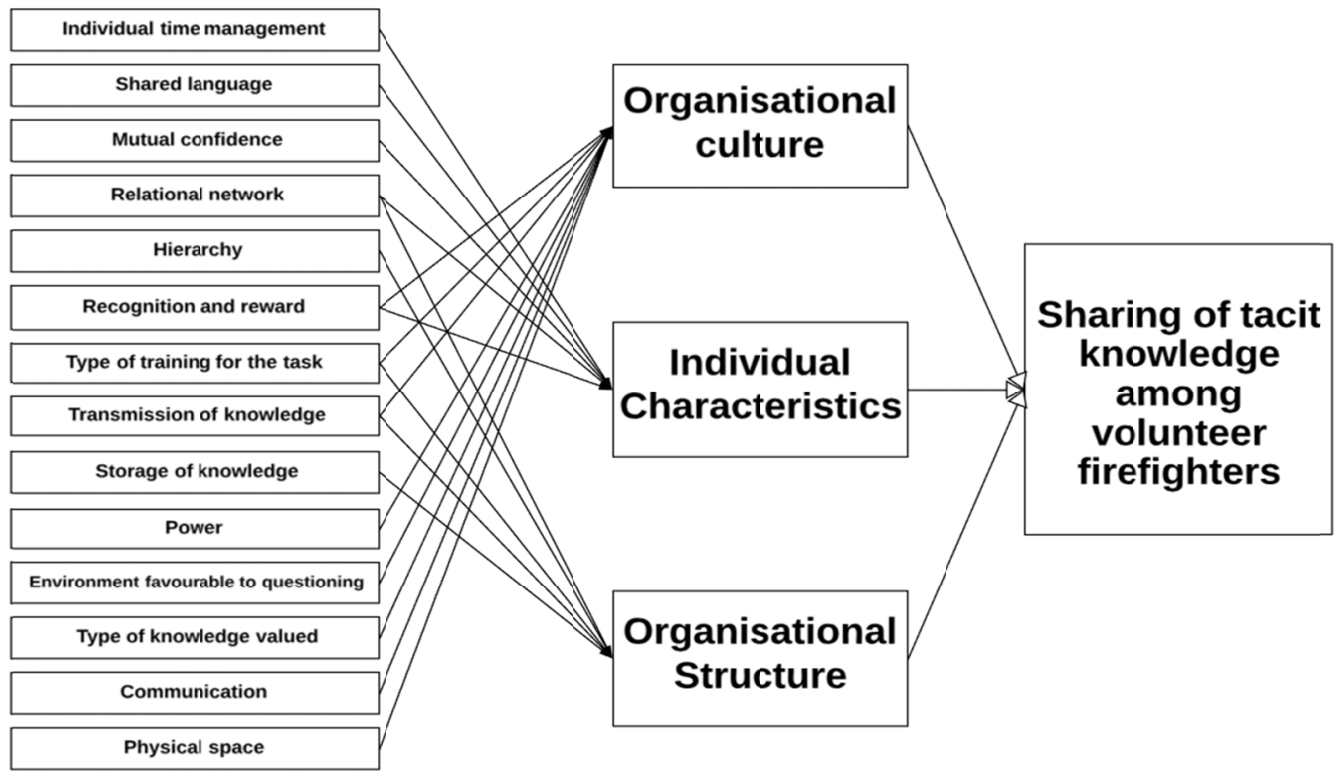

Figure 1. Indicators and factors for the sharing of tacit knowledge among VFs

\begin{abstract}
"Organisational culture" represents the first factor identified in this study. This factor spans the system for recognition and reward in effect in the organisation and that motivates the continued sharing of tacit knowledge among firefighters (Szulanski, 1996; Disterer, 2003; Haldin-Herrgard, 2000); the promotion of training types for the task of knowledge sharing that prioritise tacit knowledge and, as examples, coaching and mentoring (Joia, 2007; Disterer, 2003; Leonard \& Sensiper, 1998); the transmission of knowledge based essentially on personal and informal conversations (Nonaka \& Takeuchi, 1995; Leonard \& Sensiper, 1998; Hansen, Nohria, \& Tierney, 1999; Joia, 2007); knowledge not being perceived as a source of power (Szulansky, 1996; Davenport \& Prusak, 1998; Disterer, 2003); the prevalence of an environment favourable to questioning (Sun and Scott, 2005); a culture that distinguishes and values individual knowledge and intuition (Lemos \& Joia, 2012); a communications system based on verbal communication or conversations among firefighters (Leonard \& Sensiper, 1998; Haldin-Herrgard, 2000); and the existence of physical spaces appropriate to fostering the sharing of tacit knowledge (Young, 2010).
\end{abstract}

The second factor hereby identified encapsulates the "individual characteristics". This factor takes into account the individual management of time that enables firefighters to have the time available for this sharing of knowledge (Haldin-Herrgard, 2000; Fahey \& Prusak, 2001); the utilisation of common language that ensures such knowledge gets conveyed effectively and efficiently (Szulanski, 1996; Haldin-Herrgard, 2000, Davenport \& Prusak, 1998; Disterer, 2003); the predominance of a feeling of mutual trust that reduces uncertainties and distrust among fire crews and brings about an environment favourable to the sharing of tacit knowledge (Roberts, 2000; Davenport and Prusak, 1998); the availability of a good relational network that enables each firefighter to know somebody within the organisation who holds the knowledge needed to boost their own competences and tacit knowledge (Szulanski, 1996; O’Dell \& Grayson, 1998); and the prevalence of a system of recognition and rewards that motivates firefighters to engage in the greater sharing of this knowledge (Szulanski, 1996; Disterer, 2003; Haldin-Herrgard, 2000).

The third factor identified is that of "organisational structure". This factor considers the diagnosis made of the hierarchical VF structure as regards the needs for tacit knowledge that may exist and the availability of an internal relational network (Disterer, 2003; O’Dell \& Grayson, 1998); the proximity among the different 
members that make up the VF hierarchical structure, which enable any member, however low their ranking in this hierarchy and potentially also holding lower levels of tacit knowledge, to access those holding senior positions in this same hierarchy and correspondingly likely to have acquired greater amounts of tacit knowledge (Disterer, 2003; O'Dell and Grayson, 1998); the availability or promotion of techniques or strategies such as coaching or mentoring that prioritises the sharing of tacit knowledge and the provision of specific types of training for this task of sharing by the organisational structure (Joia, 2007; Disterer; 2003; Leonard \& Sensiper, 1998); the holding of informal conversations and personal contacts that facilitate this sharing of knowledge among the firefighters (Nonaka \& Takeuchi, 1995; Leonard \& Sensiper, 1998; Hansen, Nohria \& Tierney, 1999; Joia, 2007); and prioritising people to the detriment of databases as best practice in the different means of storing knowledge (Hansen, Nohria \& Tierney, 1999).

VFs fundamentally need to gain a perception of the importance of these three factors so as to be able to ensure the sharing of tacit knowledge increases their capacities for response. Enabling this sharing also brings about the swifter integration of newer and still learning firefighters, enabling their easier incorporation into teams, which may help in combating the lack of candidates experienced by some fire brigades.

For future studies, and given we here deal with non-profit organisations, we would recommend the drafting of a study able to evaluate the impact of this sharing of knowledge on organisational performance as regards achieving the institutional mission. We would also suggest carrying out studies that identify the barriers to the sharing of tacit knowledge in the context of this organisational type alongside the means to overcome them.

\section{References}

Caruana, A., Morris, M., \& Vella, A. (1998). The effect of centralization and formalization on entrepreneurship in export firms. Journal of Small Business Management, 36(2), 16-29. Retrieved from

https://www.researchgate.net/publication/258840584_The_Effect_of_Centralization_and_Formalizatio n_on_Entrepreneurship_in_Export_Firms

Cross, R. et al. (2001). Knowing what we know: supporting knowledge creation and sharing in social $\begin{array}{llll}\text { networks. Organizational } & \text { Bynamics, } & \text { 100-120. }\end{array}$ http://dx.doi.org/10.1016/S0090-2616(01)00046-8

Davenport, T. H., \& Prusak, L. (1998). Working Knowledge. Boston: Harvard Business School Press.

De Long, D. W., \& Fahey, L. (2000). Diagnosing cultural barriers to knowledge management. Academy of Management Executive, 14(4), 113-127. http://doi.org:10.5465/AME.2000.3979820

Disterer, G. (2003). Fostering knowledge sharing: why and how? In IADIS International Conference E-Society, Lisbon. Retrieved

from http://www.iadisportal.org/digital-library/fostering-knowledge-sharing-why-and-how

Eppler, M. J., \& Sukowski, O. (2000). Managing team knowledge: core processes, tools and enabling factors. European Management Journal, 18(3), 334-341. Retrieved from http://www.sciencedirect.com/science/article/pii/S0263237300000153

Fahey, L., \& Prusak, L. (1998). The eleven deadliest sins of knowledge management. California Management Review, 40(3), 265-276. http://dx.doi.org/10.2307/41165954

Frappaolo, C., \& Wilson, L. (2003). After the gold rush: harvesting corporate knowledge resources. Intelligent KM. Retrieved from http://www.intelligentkm.com/feature/feat1.shtml

Goffin, K., \& Koners, U. (2011). Tacit Knowledge, Lessons Learnt, and New Product Development. Journal of Product Innovation Management, 28(2), 300-318. https://doi.org/10.1111/j.1540-5885.2010.00798.x

Gottschalk, P. (2000). Strategic knowledge networks: the case of IT supports for Eurojuris law firms in Norway. International Review of Law Computers \& Technology, 14(1), 115-129. https://doi.org/10.1080/13600860054953

Hair, J. F. et al. (2005). Análise Multivariada de Dados (5th ed.). Porto Alegre: Bookman.

Haldin-Herrgard, T. H. (2000). Difficulties in the Diffusion of Tacit Knowledge in Organizations. Journal of Intellectual Capital, 1(4), 357-365. http://dx.doi.org/10.1108/14691930010359252

Hansen, M., Nohria, N., \& Tierney, T. (1999). What's your strategy for managing knowledge? Harvard Business

Review, $1-10$.

Retrieved

from 
https://hbr.org/1999/03/whats-your-strategy-for-managing-knowledge

Hislop, D. (2009). Knowledge management in organizations: a critical introduction (2nd ed.). New York: Oxford University Press.

Hopper, M. D. (1990). Rattling SABRE-new ways to compete on information. Harvard Business Review, $68(4), 118-125$.

Ichijo, K., Krogh, G., \& Nonaka, I. (1998). Knowledge enablers. In G. Krogh, J. Roos, \& D. Kleine (Eds.), Knowing in Firms: Understanding, Managing and Measuring Knowledge (pp. 173-203). California: Sage Publications.

Ivona, O. (2009). The Importance of Tacit Knowledge Within the Organization (pp. 414-416). Retrieved from http://steconomice.uoradea.ro/anale/volume/2009/v4-management-andmarketing/73.pdf

Jeng, D., \& Dunk, N. (2013). Knowledge management enablers and knowledge creation in ERP system success. International Journal of Electronic Business Management, 11(1), 49-59. Retrieved from https://www.semanticscholar.org/paper/Knowledge-Management-Enablers-and-Knowledge-in-ERP-Je ng-Dunk/c5a2b5ab5a2165d04737b57ccb8649be77a7a82b\#extracted

Jóia, L. A. (2007). Knowledge Management Strategies: Creating and Testing a Measurement Scale. International Journal of Learning and Intellectual Capital, 4(3), 203-221. http://dx.doi.org/10.1504/IJLIC.2007.015607

Lee, J. H., \& Kim, Y. G. (2001). Effects of managerial drivers and climate maturity on knowledge management performance: empirical validation. Proceedings of Pacific Asia Conference on Information Systems, 1097-1111. $\quad$ Retrieved from https://pdfs.semanticscholar.org/3595/cdab6770567f3d1d8c7506de954b4808488b.pdf

Lemos, B., \& Jóia, L. A. (2012). Relevant factors for tacit knowledge transfer within organizations: an $\begin{array}{lllll}\text { exploratory study. Gestão } \quad \& \quad \text { Produção, } & 19(2), & \text { 233-246. }\end{array}$ http://doi.org/10.1590/S0104-530X2012000200001

Leonhard, D., \& Sensiper, S. (1998). The role of tacit knowledge in group innovation. California Management Review, 40(3), 112-25. https://doi.org/10.2307/41165946

Long, D. D. (1997). Building the knowledge-based organizations: how culture drives knowledge behaviors. Working Paper, Center for Business Innovation, Ernst \& Young LLP.

Menon, A., \& Varadarajan, R. (1992). A model of marketing knowledge use within firms. Journal of Marketing, 56, 53-71. http://doi.org/10.2307/1251986

Mládková, L. (2012). Sharing Tacit Knowledge within Organizations: Evidence from the Czech Republic. Global Journal of Business Research, 6(2), 105-115. http://dx.doi.org/10.4135/9781446217375

Mongkolajala, H., Panichpathom, S., \& Ngarmyarn, A. (2012). The Development of Tacit Knowledge Sharing behavior among Employees in Organizations. International Journal of Business and Social Research, 2(5), 158-163. Retrieved from https://mpra.ub.uni-muenchen.de/82958/

Ndlela, L. T., \& Toit, A. S. (2001). Establishing a knowledge management programme for competitive advantage in an enterprise. International Journal of Information Management, 21, 151-165. http://10.1016/S0268-4012(01)00007-X

Nonaka, I. (1994). A dynamic theory of organizational knowledge creation. Organization Science, 5(1), 14-37. http://doi.org/10.1287/orsc.5.1.14

Nonaka, I., \& Takeuchi, H. (1995). The knowledge creating company: how Japanese companies create the dynamics of innovation. Oxford: Oxford University Press.

O'Dell, C. (2002). Knowledge management new generation. Presented at the APQC's 7th Knowledge Conference, Washington DC.

O'Dell, C., \& Grayson, C. J. (1998). If only we knew what we know: identification and transfer of internal best practices. California Management Review, 40(3), 154-174. https://doi.org/10.2307/41165948

Othman, A. K., \& Abdullah, H. S. (2010). The Influence of Emotional Intelligence on Tacit Knowledge Sharing in Service Organizations. Knowledge Management in Emerging Economies: Social, Organizational and Cultural Implementation, 171-185.

Polanyi, M. (1962). Tacit knowing: Its bearing on some problems of philosophy, knowing and being: essays 
by M. Polanyi. London: Routledge and Keagan.

Polanyi, M. (1966). The tacit dimension. Chicago: University of Chicago Press.

Roberts, J. (2000). From Know-How to Show-How: Questioning the Role of Information and Communication Technologies in Knowledge Transfer. Technology Analysis and Strategic Management, 12(4), 429-443. http://dx.doi.org/10.1080/713698499

Schmidt, F. L., \& Hunter, J. E. (1993). Tacit Knowledge, Practical Intelligence, General Mental Ability, and Job Knowledge. Current Directions in Psychological Science, 2, 8-9. http://dx.doi.org/10.1111/1467-8721.ep10770456

Scott, J. E. (2000). Facilitating inter-organizational learning with information technology. Journal of Management Information Systems, 17(2), 81-113. https://doi.org/10.1080/07421222.2000.11045648

Sun, P. \& Scott, J. (2005). An investigation of barriers to knowledge transfer. Journal of Knowledge Management, 9(2), 75-90. http://dx.doi.org/10.1108/13673270510590236

Sveiby, K. E. (1997). The new organizational wealth: managing and measuring knowledge- based assets. Berrett-Koehler, San Francisco.

Szulanski, G. (1996). Exploring Internal stickiness: impediments to the transfer of best practice within the firm. Strategic Management Journal, 17, 27-43. https://doi.org/10.1002/smj.4250171105

Teece, D. J. (2000). Managing Intellectual Capital: Organizational, Strategic, and Policy Dimensions. New York, NY: Oxford University Press.

Young, M. (2010). Why educators must differentiate knowledge from experience? Journal of the Pacific Circle Consortium for Education, 22(1), 9-20. Retrieved from https://auckland.rl.talis.com/items/B46B893B-DE6B-6DCE-254C-AF35E7635D5E.html

\section{Copyrights}

Copyright for this article is retained by the author(s), with first publication rights granted to the journal.

This is an open-access article distributed under the terms and conditions of the Creative Commons Attribution license (http://creativecommons.org/licenses/by/4.0/). 